BY HUBERT STAUDIGEL, ANTHONY A.P. KOPPERS,

TERRY A. PLANK, AND BARRY B. HANAN

\title{
Seamounts in the
}

\section{Subduction Factory}

Figure 1. Simplified model of a subduction zone. The oceanic plate, including (altered) oceanic crust, sediments, and seamounts, is subducted beneath a volcanic arc where it is heated from above by the overlying slab and subarc mantle. Volatiles and melts expelled from the downgoing slab interact with and melt the subarc mantle to produce a volcanic arc. Although not depicted, some seamounts may also be decapitated in the subduction channel (see Watts et al., 2010) and be added wholesale to the forearc. Also, seamounts typically have deep flexural moats filled up with more volcanic materials, which will significantly add to the total volume of oceanic intraplate volcanic materials being subducted.

Back-arc Spreading Center

\section{Volcanic Arc}

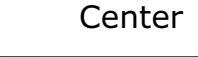


ABSTRACT. The "Subduction Factory" is a metaphor for the geochemical processing of subducted oceanic crust and sediment into components that are either incorporated into the volcanic arc or recycled into Earth's mantle. Seamounts may be a significant source of material to the Subduction Factory, in particular, by providing trace elements such as K, Ba, La, Ce, U, Th, Pb, Rb, and Cs. Seamount subduction might also play a role in the global distribution of chemical mantle heterogeneities. Neither one of these effects of seamount subduction is well understood. The Izu-Bonin-Marianas (IBM) volcanic arc is a region where the potential impact of seamount subduction may be explored most effectively. There, sections of the IBM arc and many of the incoming seamounts display unusually high ${ }^{206} \mathrm{~Pb} /{ }^{204} \mathrm{~Pb}$ ratios, which offer a particularly promising geochemical tracer that may help quantify seamount input into the Subduction Factory. Although this process remains to be explored in a quantitative manner, it is apparent that the demise of seamounts in subduction zones offers an exciting research target with important consequences for globally relevant geochemical processes.

\section{INTRODUCTION}

Every year, almost $3 \mathrm{~km}^{2}$ of oceanic crust are produced at mid-ocean ridges (Williams and von Herzen, 1974; Cogné and Humler, 2004) and subducted at convergent plate boundaries. This subduction process involves the whole plate: the oceanic crust, including its volcanic and plutonic foundation, overlying sediments, and any seamounts that are riding on top (Figure 1). As the incoming plate is subducted, it interacts physically and chemically with the overriding plate. Chemical interactions between these two plates are mostly based on dehydration reactions and, possibly, melting of the descending crust as it is squeezed and heated top-down through contact with the much hotter, convecting subarc mantle. Escaping slab fluids or melts permeate into the mantle wedge and may cause additional melting, yielding magmas that feed the volcanoes of an arc system (Figure 1). The role of subducted seamounts, and the volcaniclastic sediments they deposit around them, often is neglected in models explaining the chemical processes occurring in subduction zones (e.g., Kelley et al., 2005).

\section{THE SUBDUCTION FACTORY}

Geochemical interactions between the subducting plate and the arc system have been popularized through the concept of a "Subduction Factory" that processes the subducting oceanic crust and sediment into two fractions - a portion that interacts with the convecting subarc mantle and that rises as fluids or melts to make the volcanic arc, and a residual portion that sinks deeply into the mantle with the downgoing slab. The mass balance of these processes is key to global chemical dynamics because the volcanic arc ultimately contributes to the growth of continents. Everything that is not added to the volcanic arc system determines much of the chemical evolution of the mantle and the development of its geochemical heterogeneities.

This cycling creates chemical fluxes that have been a major control on planetary-scale chemical fractionation since the onset of plate tectonics on Earth. In its "standard model," the Subduction Factory consumes three input components to build an arc: (1) subducted sediments, (2) altered oceanic crust, and (3) the subarc mantle (Figure 1). Although seamount subduction has been considered previously, there is no systematic study that explores this effect quantitatively, and, hence, it is typically not part of Subduction Factory geochemical mass balances. Although the seamounts' total volume is much smaller than that of the oceanic crust, seamounts nevertheless could play an important role in the Subduction Factory:

- Rocks from oceanic intraplate volcanics (OIVs) introduce into the Subduction Factory larger inventories of the trace elements needed to make continental crust (e.g., K, Ba, La, Ce, $\mathrm{U}, \mathrm{Th}, \mathrm{Pb}, \mathrm{Rb}, \mathrm{Cs}$ ) when compared to normal oceanic crust, which is made up of mid-ocean ridge basalt (MORB) that is depleted in these elements. The concentration of these trace elements in OIVs can be larger by an order of magnitude or more, and therefore an equivalent mass of seamount materials contributes substantially more to this budget than does MORB.

- Large seamounts (and volcanic islands) are surrounded by aprons of volcaniclastic sediments that are shed mainly during their explosive emerging growth periods or from their collapses. These sediments carry OIV chemical signatures that are modified by intense interactions with seawater. Such aprons are particularly thick in a moat around the seamount formed by gravitational loading, 
and they may extend out for several hundred kilometers (Staudigel and Clague, 2010). At Ocean Drilling Program (ODP) Site 801 in the western Pacific, without any nearby seamounts, volcaniclastic material makes up $40 \%$ of the mass of the sediments, and provides more than $50 \%$ of the elemental budget for important subduction tracers, such as $\mathrm{Sr}, \mathrm{K}$, and Ce (Plank and Langmuir, 1998). This contribution is likely to be more pronounced closer to large seamounts.

- The actual volume of OIVs subducted is larger than revealed by the small tops of seamounts sticking out above the seafloor sediment surface because of the presence of OIV material in the volcaniclastic aprons and because a substantial amount of OIV material is covered by (pelagic) sediments. Furthermore, seamount edifices are partially sunk by the deflection of the lithosphere from seamount loading (Koppers and Watts, 2010), and additional quantities of OIV magmas also may have been intruded into the oceanic lithosphere.

- Seamount loading pushes the upper $500 \mathrm{~m}$ of intensely low-temperaturealtered oceanic crust down by several kilometers. Hence, a seamount shields the most-altered upper oceanic crust from top-down heating during subduction, resulting in delayed heating of the oceanic crust beneath the subducting seamount, possibly past the 120-km depth of arc magma generation. This would diminish the role of subducted oceanic crust in the Subduction Factory and increase the volume of altered crust subducted into the deeper mantle. Altered oceanic crust is enriched in alkali metals $(K$, $\mathrm{Rb}, \mathrm{Cs}$ ), carbonate, water, $\mathrm{Fe}^{+3}$, and radiogenic Sr (Staudigel et al., 1996), and, hence, these elements are likely to be recycled back into the deep mantle or contribute to back-arc basin magmatic processes and volatilization of the mantle by $\mathrm{CO}_{2}$ and $\mathrm{H}_{2} \mathrm{O}$-rich fluids (i.e., metasomatism).

- Seamounts, and possibly the (directly) underlying oceanic crust, are likely to be extensively altered, partly due to the more extensive exposure to water circulation and partly due to their larger abundance of volcanic glass and clastic (fragmental) rocks (see Staudigel and Clague, 2010). Prolonged access to seawater is a consequence of seamounts not being sealed by pelagic sediments (which serve to seal normal oceanic crust) and of their role as hydrothermal siphons (Fisher and Wheat, 2010). Some indication of the larger degree of alteration in seamounts is seen in the extreme alteration of a seamount/ abyssal hill at Deep Sea Drilling Project (DSDP) Site 417A in the North Atlantic on the Bermuda Rise,

Hubert Staudigel (hstaudigel@ucsd.edu) is Research Geologist and Lecturer, Institute of Geophysics and Planetary Physics, Scripps Institution of Oceanography, University of California, San Diego, La Jolla, CA, USA. Anthony A.P. Koppers is Associate Professor, College of Oceanic and Atmospheric Sciences, Oregon State University, Corvallis, OR, USA. Terry A. Plank is Professor, Lamont-Doherty Earth Observatory of Columbia University, Palisades, NY, USA. Barry B. Hanan is Staff Scientist, Department of Geological Sciences, San Diego State University, San Diego, California, USA.

where the related bulk geochemical fluxes $\left(\mathrm{K}, \mathrm{Rb}, \mathrm{Cs}, \mathrm{CO}_{2}\right)$ are much larger than in the nearby abyssal seafloor at Sites 417D and 418A (Staudigel et al., 1996).

All of these geophysical and geochemical consequences, in combination with the large numbers of seamounts, suggest that seamount subduction may be a very significant player in the dynamic geochemical system of the solid Earth.

There are several instances where seamount subduction has been invoked as part of the Subduction Factory. For example, it has been argued that the subduction of the Louisville Ridge seamounts and their associated volcaniclastics, which have the radiogenic isotope and trace element signatures associated with the Louisville mantle plume, can be traced through the Tonga subduction zone (Hawkesworth et al., 1997; Turner and Hawkesworth, 1998; Hanan et al., 2008). More recently, Hoernle et al. (2008) suggested that the subduction of the Cocos seamounts impacts mantle flow beneath the Costa Rica arc.

\section{SEAMOUNT SUBDUCTION IN} THE IZU-BONIN-MARIANA ARC The Izu-Bonin-Mariana (IBM; Figure 2) arc offers a particularly interesting scenario for studying seamount subduction and the relevant arc mass balances. It is a relatively simple subduction zone that does not have an accretionary wedge that accumulates sediments scraped off the downgoing plate. Hence, at the IBM arc, all of the oceanic crust, sediments, volcanic basement, and seamounts are subducted and thus enter the Subduction Factory. South of $25^{\circ} \mathrm{N}$, approximately 


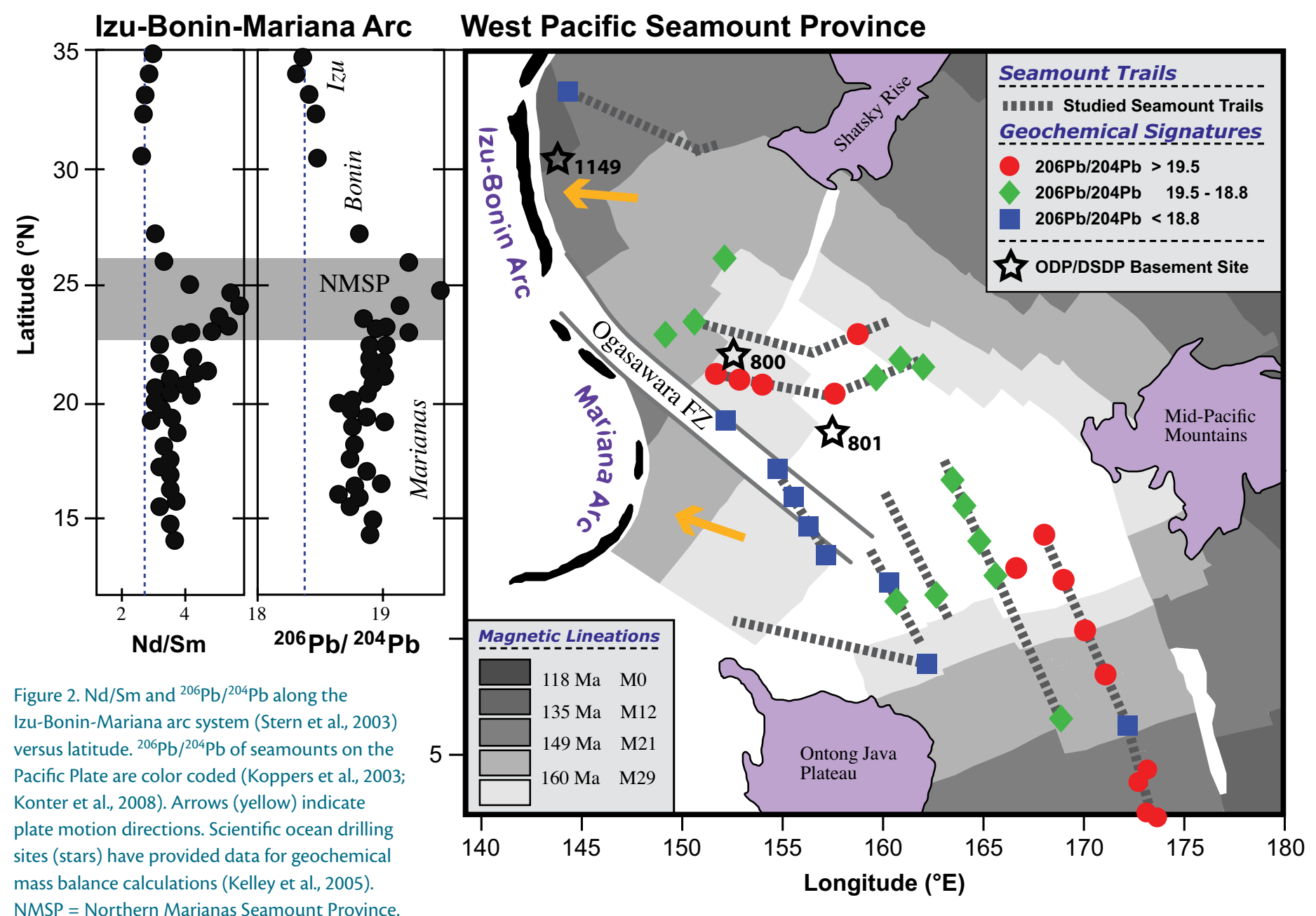

at the location of the Northern

Marianas Seamount Province (NMSP;

Figure 2), the incoming plate is littered with seamounts, but there are only a few north of this latitude. Hence, the Mariana subduction zone (including that beneath the NMSP) receives a substantial influx of seamounts, while the Izu and Bonin arcs receive almost none. Some physical evidence for seamount subduction has been suggested from the formation of serpentinite mud volcanoes in the Mariana forearc (see Spotlight 9 on page 174 of this issue [Wheat et al., 2010]; Stern et al., 2006; Oakley et al., 2008; Watts et al., 2010).

This physical evidence for seamount subduction is also supported by

geochemical data summarized in

Figure 2. Here, two geochemical parameters may be used to trace the impact of seamount subduction on arc volcanoes: (1) the rare earth element abundance ratio of $\mathrm{Nd} / \mathrm{Sm}$, and (2) the lead isotope ratio ${ }^{206} \mathrm{~Pb} /{ }^{204} \mathrm{~Pb}$. High $\mathrm{Nd} / \mathrm{Sm}$ ratios are geochemical fingerprints that indicate enrichments in light rare earth element abundances that are typical in the generation of OIV magmas through small degrees of melting of mantle materials. MORB, on the other hand, has lower $\mathrm{Nd} / \mathrm{Sm}$ ratios and is formed by higher degrees of mantle melting. High ${ }^{206} \mathrm{~Pb} /{ }^{204} \mathrm{~Pb}$ ratios (> 19.5) are rare isotopic signatures of OIV mantle sources except for those responsible in the formation of the South Pacific Isotope and Thermal Anomaly (SOPITA). SOPITA is an east-west elongated region in the mantle characterized by an unusual abundance of subducted components (Staudigel et al., 1991). These subducted components include both recycled modified oceanic crust and sediments. As a result, ${ }^{206} \mathrm{~Pb} /{ }^{204} \mathrm{~Pb}$ ratios serve as a characteristic fingerprint for the subduction of a particular subset of OIVs; thus, they may also be used to quantify seamount input into an arc system.

The IBM arc shows some rather distinct along-arc latitudinal variations in $\mathrm{Nd} / \mathrm{Sm}$ and ${ }^{206} \mathrm{~Pb} /{ }^{204} \mathrm{~Pb}$ ratios (Figure 2). Both tracers are elevated 
in the Marianas, they spike up at the NMSP, and they decline to lower values in the Izu-Bonin arc. NMSP's origin has been explained by ideas as varied as "unzipping" of the arc by coincident back-arc rifting (Stern et al., 1984), tapping enriched (Stern et al., 1993) or lithospheric mantle (Pearce et al., high ${ }^{206} \mathrm{~Pb} /{ }^{204} \mathrm{~Pb}$ ratios outboard of the Mariana arc may also extend into the subduction zone beneath this arc system. Although this scenario is very likely, we also caution that we know little about the OIV seamounts next to the trench and hence our extrapolations are tenuous. Furthermore, there can never be abso-

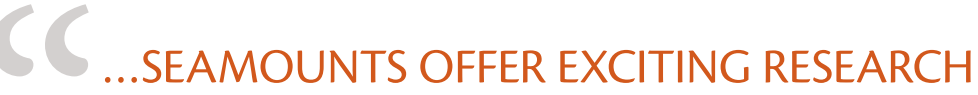 OPPORTUNITIES WITH POTENTIAL IMPLICATIONS FOR OUR UNDERSTANDING OF THE CHEMICAL EVOLUTION OF PLANET EARTH.}

2005), or an increased subduction flux of OIVs (Peate and Pearce, 1998; Sun and Stern, 2001; Sumino et al., 2004; Tollstrup and Gill, 2005; Ishizuka et al., 2007). We suggest here that the latter is more likely, largely due to the characteristic ${ }^{206} \mathrm{~Pb} /{ }^{204} \mathrm{~Pb}$ ratios of the seamounts on the subducting plate (Figure 2). There, the highest ${ }^{206} \mathrm{~Pb} /{ }^{204} \mathrm{~Pb}$ ratios (in red, Figure 2) can be found closest to the northern Marianas (i.e., the NMSP region) with nearidentical values in the seamounts and the arc. Plate motion vectors (in yellow, Figure 2) point these high- ${ }^{206} \mathrm{~Pb} /{ }^{204} \mathrm{~Pb}$ seamounts directly toward similarly high values in the IBM arc.

Recently, Konter et al. (2008) argued that high ${ }^{206} \mathrm{~Pb} /{ }^{204} \mathrm{~Pb}$ ratios appear to be a long-lived characteristic of some Pacific OIV seamounts that can be traced all the way from their original hotspot locations in the South Pacific to the seamounts shown in Figure 2. Given this longevity, the currently known lute certainty as to what geochemical component is currently located in the root zones of these arc volcanoes, and inferences have to be extrapolated from what can be sampled outboard of the subduction zone. However, successful tracing of seamounts into the arc, in combination with an understanding of the temporal and spatial variation of ${ }^{206} \mathrm{~Pb} /{ }^{204} \mathrm{~Pb}$ ratios within the arc, will help us understand the extent to which seamounts can play a role in arc magmatic processes. These geochemical constraints will, in turn, help us ultimately better understand key geophysical data sets from this arc, such as seismic anisotropy observations (Pozgay et al., 2007), and inform geodynamic models (Kneller and van Keken, 2007).

\section{OUTLOOK}

The association of high- ${ }^{206} \mathrm{~Pb} /{ }^{204} \mathrm{~Pb}$ arc volcanoes with subduction of seamounts that have high ${ }^{206} \mathrm{~Pb} /{ }^{204} \mathrm{~Pb}$ ratios at the IBM arc offers an exceptional opportunity to explore the potential involvement of OIVs in the Subduction Factory, because ${ }^{206} \mathrm{~Pb} /{ }^{204} \mathrm{~Pb}$ ratios are a particular distinctive geochemical fingerprint. Substantiation of the connection and its quantification would provide profound insights into our understanding of chemical geodynamics (see also Koppers and Watts, 2010). Most of the seamounts in Figure 1 originate in SOPITA (Staudigel et al., 1991; Koppers et al. 2003; Konter et al., 2008), and plate motion models suggest that these seamounts are heading for their ultimate "graveyard" beneath the IBM subduction zone. Subduction of these seamounts may ultimately lead to the formation of another geochemical anomaly that includes high ${ }^{206} \mathrm{~Pb} /{ }^{204} \mathrm{~Pb}$ ratios in Earth's mantle, just like those found today in SOPITA. Could that mean that SOPITA itself formed by recycling of OIVs? This possibility poses the question of what role subducted seamount graveyards play in the origin of major mantle chemical anomalies such as SOPITA in the Pacific. We believe that the cycle of birth, destruction, and rebirth of OIVs might play a fundamental role in chemical geodynamics. Even as they meet their final demise in subduction zones, seamounts offer exciting research opportunities with potential implications for our understanding of the chemical evolution of Planet Earth.

\section{ACKNOWLEDGEMENTS}

We thank R.J. Stern and J.B. Gill for insightful and constructive reviews of this manuscript. 


\section{REFERENCES}

Cogné J.P., and E. Humler. 2004. Temporal variation of oceanic spreading and crustal production rates during the last $180 \mathrm{My}$. Earth and Planetary Science Letters 227:427-439.

Fisher, A.T., and C.G. Wheat. 2010. Seamounts as conduits for massive fluid, heat, and solute fluxes on ridge flanks. Oceanography 23(1):74-87.

Hanan, B., T. Rooney, A. Pietruszka, L. Tisn, D. Hahm, P. Castillo, D. Hilton, and J. Hawkins. 2008. Hf and $\mathrm{Pb}$ isotope constraints on the source origin of Northern Lau Basin back-arc basin basalts. Geochimica et Cosmochimica Acta 72(12):A347.

Hawkesworth, C.J., S.P. Turner, F. McDermott, D.W. Peate, and P. van Calsteren. 1997. $\mathrm{U}$-Th isotopes in arc magmas: Implications for element transfer from the subducted crust. Science 276:551-555.

Hoernle, K, D.L. Abt, K.M. Fischer, H. Nichols, F. Hauff, G.A. Abers, P. van den Bogaard, K. Heydolph, G. Alvarado, M. Protti, W. Strauch. 2008. Arc-parallel flow in the mantle wedge beneath Costa Rica and Nicaragua. Nature 451:1.094-1,097, doi:10.1038/nature06550.

Ishizuka, O., R.N. Taylor, M. Yuasa, J.A. Milton, R.W. Nesbitt, K. Uto, and I. Sakamoto. 2007. Processes controlling along-arc isotopic variation of the southern Izu-Bonin arc. Geochemistry, Geophysics, Geosystems 8, Q06008, doi:10.1029/2006GC001475.

Kelley, K.A., T. Plank L. Farr, J. Ludden, and H. Staudigel. 2005. Subduction cycling of $\mathrm{U}, \mathrm{Th}$ and $\mathrm{Pb}$. Earth and Planetary Science Letters 234:369-383.

Kneller, E.A., and P.E. van Keken. 2007. Trenchparallel flow and seismic anisotropy in the Mariana and Andean subduction systems. Nature 450(7173):1,222-1,225.

Konter, J.G., B.B. Hanan, J. Blichert-Toft, A.A.P. Koppers, T. Plank, and H. Staudigel. 2008. One hundred million years of mantle geochemical history suggest the retiring of mantle plumes is premature. Earth and Planetary Science Letters 275:285-295.

Koppers, A.A.P., H. Staudigel, M.S. Pringle, and J.R. Wijbrans. 2003. Short-lived and discontinuous intraplate volcanism in the South Pacific: Hot spots or extensional volcanism? Geochemistry, Geophysics, Geosystems 4(10), 1089, doi:10.1029/2003GC000533.

Koppers, A.A.P., and A.B. Watts. 2010. Intraplate seamounts as a window into deep Earth processes. Oceanography 23(1):42-57.

Oakley, A.J., B. Taylor, and G.F. Moore. 2008. Pacific Plate subduction beneath the central Mariana and Izu-Bonin fore arcs: New insights from an old margin. Geochemistry, Geophysics, Geosystems 9, Q06003, doi:10.1029/2007GC001820.
Pearce, J.A., R.J. Stern, S.H. Bloomer, and P. Fryer. 2005. Geochemical mapping of the Mariana arc-basin system: Implications for the nature and distribution of subduction components. Geochemistry, Geophysics, Geosystems 6, Q07006, doi:10.1029/2004GC000895.

Peate, D.W., and J.A. Pearce. 1998. Causes of spatial compositional variations in Mariana arc lavas: Trace element evidence. The Island Arc 7:479-495.

Plank, T., and C.H. Langmuir. 1998. The chemical composition of subducting sediment: Implications for the crust and mantle. Chemical Geology 145:325-394

Pozgay, S.H., D.A. Wiens, J.A. Conder, H. Shiobara, and H. Sugiok. 2007. Complex mantle flow in the Mariana subduction system: Evidence from shear wave splitting. Geophysical Journal International 170(1):371-386.

Staudigel, H., K.-H. Park, M.S. Pringle, J.L. Rubenstone, W.H.F. Smith, and A. Zindler. 1991. The longevity of the south Pacific isotope and thermal anomaly. Earth and Planetary Science Letters 102:24-44.

Staudigel, H., T. Plank, W. White, and H.-U. Schmincke. 1996. Geochemical fluxes during seafloor alteration of the basaltic upper oceanic crust: DSDP Sites 417-418 (Overview). Pp. 19-38 in Subduction Top to Bottom. G.E. Bebout, D.W. Scholl, S.H. Kirby, and J.P. Platt, eds, American Geophysical Union Monograph Series 96, Washington, DC.

Staudigel, H., and D.A. Clague. 2010. The geological history of deep-sea volcanoes: Biosphere, hydrosphere, and lithosphere interactions. Oceanography 23(1):58-71.

Stern, R.J., N.C. Smoot, and M. Rubin. 1984. Unzipping of the volcano arc, Japan. Tectonophysics 102:153-174.

Stern, R.J., M.C. Jackson, P. Fryer, and E. Ito. 1993. $\mathrm{O}, \mathrm{Sr}, \mathrm{Nd}$ and $\mathrm{Pb}$ isotopic composition of the Kasuga cross-chain in the Mariana arc: A new perspective on the K-h relationship. Earth and Planetary Science Letters 119:459-475.

Stern, R.J., E. Kohut, S.H. Bloomer, M. Leybourne, M. Fouch, and J. Vervoot. 2006. Subduction factory processes beneath the Guguan crosschain, Mariana Arc: No role for sediments, are serpentinites important? Contributions to Mineralogy and Petrology 151(2):202-221.

Stern, R.J., M.J. Fouch, and S.L. Klemperer. 2003. An overview of the Izu-Bonin-Mariana subduction factory. Pp. 175-222 in Inside the Subduction Factory. J. Eiler, ed., Geophysical Monograph Series Volume 138, American Geophysical Union, Washington, DC.

Sumino, H., K. Notsua, S. Nakaib, M. Satoa, K. Nagaoa, M. Hosoec, and H. Wakitaa. 2004. Noble gas and carbon isotopes of fumarolic gas from Iwojima Volcano, Izu-Ogasawara arc, Japan: Implications for the origin of unusual arc magmatism. Chemical Geology 209:153-173.
Sun, C-H., and R.J. Stern. 2001. Genesis of Mariana shoshonites: Contribution of the subduction component. Journal of Geophysical Research 106:589-608.

Turner, S., and C. Hawkesworth. 1998. Using geochemistry to map mantle flow beneath the Lau Basin. Geology 26:1,019-1,022.

Tollstrup, D.L., and J.B. Gill. 2005. Hafnium systematics of the Mariana arc: Evidence for sediment melt and residual phases. Geology 33:737-740.

Watts, A.B., A.A.P. Koppers, and D.P. Robinson. 2010. Seamount subduction and earthquakes. Oceanography 23(1):166-173.

Wheat, C.G., P. Fryer, K. Takai, and S. Hulme. 2010. Spotlight 9: South Chamarro Seamount. Oceanography 23(1):174-175.

Williams, D.L., and R.P. von Herzen. 1974. Heat loss from the Earth: new estimate. Geology 2:327-328.

Zindler, A., and S. Hart. 1986. Chemical geodynamics. Annual Review of Earth and Planetary Sciences 14:493-571. 